\title{
GANTI RUGI SEBAGAI PERLINDUNGAN HUKUM \\ BAGI KONSUMEN AKIBAT PRODUK CACAT
}

\author{
Fabian Fadhly \\ Universitas Katolik Parahyangan \\ J1. Ciumbuleuit 94 Bandung 40141 Tlp. (022) 203655, fax. (022) 2031110 \\ Email: fabianfadhly@ymail.com
}

\begin{abstract}
Compensation is a method that can be used in consumer protection from defective product that produce by producer. Therefore, this paper explore compensation with it form as consumer protection. Juridis normative with descriptive analytis aprroach is research method that use in this paper. The producer have liability to give compensation to consumer that used defective product, with to percieve calculated concret and/or past loss, and also to consider the consumer obligation as the right of producer have been done, it form can be money because the simplicity term.
\end{abstract}

Key words: compensation, protection, consumer, producer, defective product

\begin{abstract}
Abstrak
Ganti rugi merupakan sarana yang dapat digunakan untuk memberikan perlindungan bagi konsumen terhadap produk cacat yang diproduksi oleh pelaku usaha. Oleh sebab itu, tulisan ini mengkaji mengenai ganti rugi serta bentuknya akibat produk cacat sebagai upaya perlindungan bagi konsumen. Pendekatan normatif yuridis dengan deskriptif analitis merupakan metode penelitian yang digunakan dalam tulisan ini. Produsen mempunyai tanggung jawab untuk memberikan ganti rugi kepada konsumen, akibat menggunakan atau mengonsumsi produk cacat, dengan memperhatikan kerugian nyata dan yang dapat diduga, dan mempertimbangkan kewajiban konsumen yang menjadi hak produsen telah dilaksanakan. Bentuk ganti rugi yang diberikan kepada konsumen berupa uang karena sifatnya yang praktis
\end{abstract}

Kata kunci: ganti rugi, perlindungan, konsumen, pelaku usaha, produk cacat

\section{Latar Belakang}

Pembangunan dan perkembangan perekonomian khususnya di bidang perindustrian dan perdagangan nasional telah menghasilkan berbagai variasi barang/jasa yang dapat dikonsumsi. Selain itu, globalisasi dan perdagangan bebas yang didukung oleh kemajuan teknologi telekomunikasi informatika telah memperluas ruang gerak arus transaksi barang dan/atau jasa yang ditawarkan bervariasi baik produksi dalam maupun produksi luar negeri. ${ }^{1}$

Kondisi yang demikian pada satu pihak mempunyai manfaat bagi konsumen karena

1 Undang-Undang Nomor 8 Tahun 1999 tentang Perlindungan Konsumen Bagian Penjelasan Umum. 
kebutuhan konsumen akan barang dan/atau jasa yang diinginkan dapat terpenuhi serta semakin terbuka lebar kebebasan untuk memilih aneka jenis dan kuantitas barang dan/atau jasa sesuai dengan keinginan dan kemampuan konsumen. ${ }^{2}$

Kemudahan tersebut pada sisi lain dapat berpotensi memunculkan kemungkinan berbagai kerugian yang akan diderita oleh konsumen, akibat transaksi perindustrian dan perdagangan yang bersifat global dengan didukung kemajuan yang sangat pesat pada bidang informasi telekomunikasi, yang dapat mengakibatkan kedudukan pelaku usaha dan konsumen menjadi tidak seimbang konsumen berada pada posisi yang lemah.

Keadaan konsumen yang berada pada posisi lemah ini dimaknai sebagai bagian dari ketidakmampuan konsumen dalam memahami hak dan kewajiban yang dimilikinya, pandangan ini lahir dikarenakan tidak setiap konsumen memiliki pengetahuan dan pemahaman yang sama mengenai hak dan kewajiban yang berada dalam terma hukum perlindungan konsumen.

Kurangnya pengetahuan dan pemahaman inilah yang menyebabkan konsumen menjadi objek bisnis untuk meraup keuntungan yang sebesar-besarnya oleh pelaku usaha. Salah satu bagian perlindungan terhadap konsumen dari perilaku pelaku usaha yang menjadikannya hanya sebagai objek bisnis, sehingga dapat mendatangkan kerugian bagi konsumen adalah melalui ganti rugi terhadap dari produk cacat yang dikonsumsi atau digunakan oleh konsumen.

Produk cacat di Indonesia didefinisikan sebagai produk yang tidak dapat memenuhi tujuan pembuatannya baik karena kesengajaan atau kealpaan dalam maupun disebabkan hal-hal lain yang terjadi dalam peredarannya, atau tidak menyediakan syarat-syarat keamanan bagi manusia atau harta benda mereka dalam penggunaannya, sebagaimana diharapkan konsumen. ${ }^{3}$

Contoh produk cacat Badan Pengawas Obat dan Makanan (BPOM) Surabaya telah melakukan penyitaan puluhan karton berisi kemasan sachet obat penguat stamina tradisional dari gudang milik Safianton, Obat kuat tradisional berbagai merek mengandung Bahan Kimia Obat (BKO) dan masuk kategori dalam public warning. Kepala Seksi Penyidikan BB POM Surabaya, Siti Amanah menyatakan bahwa, produk obat kuat dan jamu tradisional berbahan kimia itu, masuk dalam kategori public warning BB POM dan dilarang beredar di pasaran. Sesuai dengan ketentuan, obat-obat tradisional seharusnya berbahan herbal dan tidak mengandung bahan kimia. ${ }^{4}$ Contoh lain Balai Besar Pengawas Obat dan Makanan (BPOM) Kota Surabaya melakukan

2 Ibid.

3 A. Z. Nasution, Hukum Perlindungan Konsumen Suatu Pengantar, Diadit Media, Yogyakarta, 2001, hlm. 248.

4 Arie Yoenianto, Awas! Obat Kuat Berbahaya Beredar di Pasaran, http://daerah.sindonews.com/ $\mathrm{read} / 2014 / 03 / 27 / 23 / 848031 /$ awas-obat-kuat-berbahaya-beredar-di pasaran, diakses 29 Maret 2014 pukul 15.40. WIB. 
penyitaan terhadap gudang penyimpanan bahan berbahaya berupa boraks, dan boraks tersebut umumnya digunakan sebagai bahan campuran makanan, sebagaimana dikatakan Kepala Balai BPOM Surabaya Endang Pudjiwati. $^{5}$

Penggunaan zat berbahaya seperti boraks, rhodamine, apabila dikonsumsi dalam jumlah berlebih dan jangka panjang akan menimbulkan mutasi genetik, kanker, dan keracunan pada alat-alat reproduksi manusia. Apabila masuk ke tubuh ibu yang sedang mengandung dan menyusui, zat ini akan mempengaruhi perkembangan perilaku pada bayi, gangguan hormonal, dan cacat lahir.

Melihat beberapa kasus yang menimpa konsumen di atas bahwa kerugian dapat berasal dari produk cacat, yang memungkinkan konsumen mengalami kerugian tidak serta merta dialami ketika produk tersebut dikonsumsi atau digunakan. Kerugian tersebut dapat berupa cacat atau bahkan mungkin kematian sebagaimana dijelaskan pada kedua contoh di atas.

Kerugian yang diderita oleh konsumen akibatmengonsumsiataumenggunakanproduk cacat tersebut, memberikan konsekuensi berupa tanggungjawab yang dibebankan kepada pelaku usaha untuk memberikan ganti rugi, sebagaimana dinyatakan pada Pasal 19 ayat (1) Undang-undang Nomor 8 Tahun 1999 tentang Perlindungan Konsumen (UUPK), tanggung jawab pelaku usaha, meliputi: ${ }^{6}$

1. Tanggung jawab ganti kerugian atas kerusakan;

2. Tanggung jawab ganti kerugian atas pencemaran;

3. Tanggung jawab ganti kerugian atas kerugian konsumen.

Pasal 19 ayat (2) UUPK lebih lanjut mengatur bentuk ganti rugi yang dapat diperoleh konsumen akibat mempergunakan atau mengonsumsi produk cacat (defective product) yaitu:

“Ganti rugi sebagaimana dimaksud ayat (1) dapat berupa pengembalian barang/atau jasa yang sejenis atau setara nilainya, atau perawatan kesehatan dan/atau pemberian santunan yang sesuai dengan ketentuan peraturan perundangundangan yang berlaku."

Pemberian ganti rugi berkaca dari tiga hal, yaitu: cidera pribadi (termasuk di dalamnya kematian atau gangguan mental), kerusakan barang pribadi (property) dan pada beberapa keadaan kehilangan keuntungan ekonomi. Tujuan utamanya adalah memberikan hukuman berupa kewajiban membayar kompensasi kepada konsumen akibat tindakan yang dilakukan oleh produsen. ${ }^{7}$

5 Nurul Arifin, BPOM Surabaya Gerebek Gudang Penyimpanan Boraks, http://daerah.sindonews.com/ $\mathrm{read} / 2014 / 03 / 26 / 23 / 848001 /$ bpom-surabaya-gerebek-gudang-penyimpanan-boraks, diakses 29 Maret 2014 pukul 15.45 WIB.

6 Ahmadi Miru dan Sutarman Yodo, Hukum Perlindungan Konsumen, Rajawali Pers, Jakarta, 2005, hlm. 127.

7 David Oughton and John Lowry, Question \& Answers Law of Torts, Blackstone Press Limited, London, 1999, hlm. 223. 
Gantirugi dimaksudkanuntuk memulihkan keadaan yang telah menjadi rusak (tidak seimbang akibat adanya penggunaan barang atau jasa yang tidak memenuhi harapan konsumen). Hak ini sangat terkait dengan produk yang telah merugikan konsumen baik berupa kerugian materi, maupun kerugian yang menyangkut diri (sakit, cacat, bahkan kematian). ${ }^{8}$

Pemulihan keadaan yang telah menjadi rusak ini didasarkan kepada ajaran/teori faktor kelayakan yang disebut dengan ajaran atau teori dipertanggungjawabkan secara layak (toerrekening naar redelijkheid), faktorfaktor penting yang mempengaruhi teori tersebut adalah:

1. Sifat dari kejadian yang menjadi dasar pertanggung gugat;

2. Sifat kerugian;

3. Besar kecilnya kerugian yang akan diperkirakan akan terjadi; dan

4. Beban seimbang yang dapat dilakukan bagi pihak tergugat dari kewajibannya untuk membayar ganti rugi, serta memperhatikan keadaan keuangan pihak yang dirugikan. ${ }^{9}$

Code Civil Perancis merinci ganti rugi dalam 2 (dua) unsur yaitu dommages dan interest. Dommages meliputi apa yang dinamakan biaya dan rugi, sedangkan interest sama dengan bunga dalam arti keuntungan yang diharapkan atau yang sudah diperhitungkan. ${ }^{10}$

Abdulkadir Muhammad mempertegas pernyataan di atas bahwa ganti rugi itu terdiri dari 3 (tiga) unsur, yaitu

1. Ongkos atau biaya yang telah dikeluarkan, misalnya ongkos cetak, biaya materai, biaya iklan;

2. Kerugian sesungguhnya karena kerusakan, kehilangan benda milik kreditur akibat, misalnya membusuknya buah-buahan karena keterlambatan penyerahan, ambruknya rumah karena konstruksi, sehingga merusak perabotan rumah tangga;

3. Bunga atau keuntungan yang diharapkan, misalnya bunga berjalan selama piutang terlambat diserahkan (dilunasi), keuntungan yang diperoleh karena keterlambatan. ${ }^{11}$

Berdasarkan uraian di atas, permasalahan yang diangkat adalah:

1. Apakah ganti rugi dapat diberikan sebagai upaya perlindungan bagi konsumen akibat produk cacat yang diproduksi oleh pelaku usaha?

2. Bagaimanakah bentuk ganti rugi akibat produk cacat yang diproduksi oleh pelaku usaha sebagai upaya perlindungan bagi konsumen?

\footnotetext{
8 Ahmadi Miru dan Sutarman Yodo, Hukum Perlindungan Konsumen, Op.cit., hlm. 126.

9 Ibid, hlm. 136.

10 Riduan Syahrani, Seluk-Beluk dan Asas-asas Hukum Perdata, Alumni, Bandung, 2004, hlm. 223.

11 Abdulkadir Muhammad, Hukum Perdata, Citra Aditya Bakti, Bandung, 2000, hlm. 207.
} 
Berdasarkan permasalahan di atas, tujuan yang diangkat adalah:

1. Memberikan pemahaman yang mendalam mengenai ganti rugi akibat produk cacat sebagai upaya perlindungan bagi konsumen .

2. Memberikan pemahaman yang mendalam mengenai bentuk ganti akibat produk cacat sebagai upaya perlindungan bagi konsumen.

Tulisan ini dibuat berdasarkan hasil penelitian yuridis normatif dengan menggunakan metode deskriptif analitis. Penelitian ditujukan untuk menganalisis bahan-bahan hukum yang mengacu kepada norma-norma hukum yang terdapat dalam peraturan perundang-undangan dan putusan pengadilan. $^{12}$

Penelitian ini dilakukan melalui penelitian kepustakaan (library research) atau dokumen peraturan perundang-undangan seperti Kitab Undang-undang Hukum Perdata, Undangundang Nomor 8 Tahun 1999 Tentang Perlindungan Konsumen, buku, jurnal hukum, dan berbagai putusan pengadilan yang berkaitan dengan ganti rugi pada produk cacat.

\section{Pembahasan}

\section{A. Produk dan Produk Cacat}

Produk dapat diartikan sebagai barang, konotasi akan kedua kata ini dapat dipahami melalui pengertian barang dalam Pasal 1 ayat (4) Undang-undang Nomor 8 Tahun 1999 tentang Perlindungan Konsumen

"Barang adalah setiap benda baik berwujud maupun tidak berwujud, baik bergerak, dapat dihabiskan maupun tidak dapat dihabiskan, yang dapat untuk diperdagangkan, dipakai, dipergunakan, atau dimanfaatkan oleh konsumen".

Endang Saefullah menyatakan hal yang serupa mengenai makna dan/atau cakupan mengenai produk, Produk diartikan sebagai barang yang secara nyata dapat dilihat dan dipegang (tangible goods), baik yang bergerak maupun tidak bergerak. Namun dalam masalah tanggung jawab produsen (product liability). ${ }^{13}$

Produk bukan hanya berupa tangible goods tapi juga termasuk yang bersifat intangible goods seperti listrik, produk alami (misal makanan binatang peliharaan dengan jenis binatang lain), tulisan (misal peta penerbangan yang diproduksi secara masal), atau perlengkapan tetap pada rumah real estate (misal berbagai fasilitas rumah). ${ }^{14}$

\footnotetext{
12 Ridwan Khairandy, Landasan Filosofis Kekuatan Mengikatnya Kontrak, Jurnal Hukum, Edisi khusus, 18 Oktober 2011, Fakultas Hukum Universitas Islam Indonesia (UII), Yogyakarta, 2011, hlm. 39.

13 Endang Saefullah, Tanggung Jawab Produsen di Era Perdagangan Bebas, makalah disajikan dalam Seminar Perspektif Hukum Perlindungan Konsumen dalam Era Perdagangan Bebas, Universitas Islam Bandung, 9 Mei 1998, hlm. 35.

14 Ibid, hlm. 35.
} 
Philip Kotler, menengahi dengan memberikan batasan yang termasuk ke dalam pengertian produk adalah sesuatu yang dapat ditawarkan ke dalam pasar untuk diperhatikan, dimiliki, dipakai, atau dikonsumsi, sehingga dapat memuaskan keinginan atau kebutuhan. ${ }^{15}$

Tim Kerja Penyusun Naskah Akademik Badan Pembinaan Hukum Nasional Departemen Kehakiman Republik Indonesia merumuskan pengertian produk cacat sebagai berikut: ${ }^{16}$

"Setiap produk yang tidak dapat memenuhi tujuan pembuatannya, baik karena kesengajaan, atau kealpaan dalam proses produksinya maupun disebabkan hal-hal yang akan terjadi dalam peredarannya, atau tidak menyediakan syaratsyarat keamanan bagi manusia atau harta benda mereka dalam penggunaannya, sebagai layaknya diharapkan orang”.

Produk yang cacat/rusak (defective product) yang menyebabkan produsen harus bertanggungjawab, dikenal tiga macam defect, yaitu production/manufacturing defect, design defect, dan warning or instruction defect. ${ }^{17}$
Production/manufacturing defect yaitu keadaan produk yang umumnya berada di bawah tingkat harapan konsumen, atau apabila produktersebuttidaksesuaidengan persyaratan sehingga akibatnya produk tersebut tidak aman bagi konsumen. Manufacturing defect dapat diartikan pula sebagai hubungan antara kesesuaian perincian, kepuasan, pemakai, dan penyimpangan dari ketentuan. ${ }^{18}$

Kewajiban untuk bertanggung jawab yang dimiliki oleh pelaku usaha akibat produk cacat, pada mulanya hanya dikhususkan untuk produk makanan dan minuman, akan tetapi dengan berjalannya waktu kekhususan tersebut diperluas kepada seluruh produk yang diproduksi. ${ }^{19}$

Design defect dapat didefinisikan sebagai permintaan pada umumnya terlalu banyak bahaya yang dapat dicegah. Produknya mungkin saja tidak sempurna jika gagal menampilkan sebisa mungkin seperti yang diharapkan oleh konsumen pada umumnya. Konteks ini diartikan sebagai sesuatu yang diharapkan, yang diduga memiliki pengertian diramalkan dalam kegagalan bentuk. ${ }^{20}$ Cacat desain ini terjadi pada tingkat persiapan produk, terdiri dari atas desain, komposisi atau konstruksi. ${ }^{21}$

15 Widyaningtyas Sistaningrum, Manajemen Penjualan Produk, Kanisius, Yogyakarta, 2002, hlm. 1.

16 A. Z. Nasution, Op.cit., hlm. 1.

17 Endang Saefullah, log.cit.

18 Amaliyah, Perlindungan Konsumen atas Bahan Tambahan Pangan pada UU No. 8 Tahun 1999 tentang Perlindungan Konsumen jo UU No. 7 Tahun 1996 tentang Pangan, Skripsi Program Sarjana Ilmu Hukum pada Fakultas Hukum Universitas Islam Bandung, 2003, tidak dipublikasikan, hlm. 49.

19 David Ouhgton and John Lowry, Text Book on Consumer Law, Blackstone Press Limited, London, 1997, hlm. 185.

20 Ibid, hlm. 50.

21 Ahmadi Miru, Prinsip-Prinsip Perlindungan Hukum bagi Konsumen di Indonesia, Rajawali Pers, Jakarta, 2011, hlm. 26. 
Warning/insrtuction defect, suatu produk termasuk ke dalam kategori ini apabila memenuhi kriteria-kriteria sebagai berikut:

Pertama, Product labelling merupakan salah satu cara untuk melindungi konsumen pada saat tertentu, hal tesebut sama dengan menjamin terselenggaranya market transparency, pelabelan produk pada waktu tertentu memiliki peran yang langsung untuk memberikan jaminan dalam rangka melindungi fisik konsumen dengan memberikan peringatan tentang produk berbahaya. ${ }^{22}$

Zaman yang terus berkembang menyebabkan lahirnya inovasi-inovasi baru berkenaan pelabelan suatu produk dalam upaya melindungi konsumen dari hal-hal yang tidak diinginkan. Contoh akan perkembangan ini tampak bagaimana regulasi label di banyak negara, tidak cukup suatu produk hanya memberikan penjelasan tentang kandungan produk tersebut, tetapi menjadi kewajiban untuk mencantumkan asal-usul produk tersebut, proses pembudidayaan produk tersebut. Kewajiban ini diperuntukkan bagi produk pangan. ${ }^{23}$

Kedua, Advertisements (iklan) berisi tentang informasi tertentu, misalnya tentang paket liburan yang terdiri dari brosur harus dengan jelas dan akurat memberikan harga dan informasi yang berkaitan dengan tujuan liburan, transportasi, akomodasi (lokasi, kualitas kenyamanan, keistimewaan tempat tujuan), termasuk di dalamnya makanan dan buku perjalanan. ${ }^{24}$

Produk maupun produk cacat mempunyai persamaan yaitu, barang yang dinginkan atau dibutuhkan oleh konsumen, didapatkan dengan cara penawaran di pasar dalam rangka memenuhi kebutuhannya, perbedaannya yang paling tampak adalah bahwa produk cacat merupakan barang yang tidak sesuai dengan peruntukannya atau kebutuhannya, sebaliknya barang yang sesuai dengan peruntukannya disebut produk.

\section{B. Konsumen dan Pelaku Usaha}

Konsumen merupakan golongan yang rentan dieksploitasi oleh pelaku usaha, oleh karena itu diperlukan seperangkat aturan hukum untuk melindungi konsumen, sehingga dengan adanya perangkat hukum tersebut dapat memberikan rasa aman dan nyaman terhadap dirinya dalam mengonsumsi atau menggunakan produk dari pelaku usaha.

Konsumen berdasarkan Pasal 1 angka 1 UUPK diartikan sebagai berikut:

"Setiap orang pemakai barang dan atau jasa yang tersedia dalam masyarakat, baik bagi kepentingan diri sendiri, keluarga, orang lain, maupun makhuk hidup lain dan tidak diperdagangkan”.

22 Colin Scot and Julian Black, Craston's Consumer and the Law (third edition), Butterworths, London, 2000, hlm. 340.

23 Sudaryatmo, Hukum Perlindungan Konsumen dan Implementasinya di Indonesia, Jurnal Hukum Bisnis, Volume 30, No. 1, Tahun 2011, Yayasan Pengembangan Hukum Bisnis (YPHB), Jakarta, hlm. 38.

24 Colin Scot and Julian Black, Op.cit., hlm. 341. 
Konsumen pada pasal ini dimaknai sebagai konsumen akhir yaitu pengguna atau pemanfaat akhir dari suatu produk, dan konsumen antara yaitu konsumen yang menggunakan suatu produk sebagai bagian dari proses produksi suatu produk lainnya. Konsumen pada UUPK adalah konsumen akhir. Konsumen tidak hanya dikualifikasikan subjek hukum dalam arti orang akan tetapi termasuk pula di dalamnya badan hukum sebagai konsumen akhir yaitu badan hukum yang mengonsumsi barang dan/atau jasa serta tidak diperdagangkan. ${ }^{25}$

Hak-hak perlindungan hukum bagi konsumen di Indonesia, secara ekspilsit dituangkan dalam Pasal 4 UUPK:

a. Hak atas kenyamanan, keamanan, dan keselamatan dalam mengonsumsi barang dan/atau jasa;

b. Hak untuk memilih barang dan/atau jasa serta mendapatkan barang dan/atau jasa tesebut sesuai dengan nilai tukar dan kondisi serta jaminan yang dijanjikan.

c. Hak atas informasi yang benar, jelas dan jujur mengenai kondisi serta jaminan barang dan/atau jasa;

d. Hak untuk didengar pendapat dan keluhannya atas barang dan/atau jasa yang digunakan;

e. Hak untuk mendapatkan advokasi, perlindungan dan upaya penyelesaian sengketa perlindungan secara patut; f. Hak untuk mendapatkan pembinaan dan pendidikan hukum;

g. Hak untuk diperlakukan atau dilayani secara benar dan jujur tidak diskriminatif;

h. Hak untuk mendapatkan dispensasi, ganti rugi, dan atau penggantian barang dan/atau jasa yang diterima tidak sesuai dengan perjanjian atau tidak sebagaiman mestinya;

i. Hak-hak yang diatur dalam ketentuan peraturan-perundangan yang lain.

Hak-hak ini muncul sebagai kewajiban yang dibebankan kepada pelaku usaha karena produknya menyebabkan luka bagi konsumen, walaupun tidak berdasarkan kontrak antara pelaku usaha dengan konsumen. Pertimbangan ini timbul dikarenakan pelaku usaha mempunyai kewajiban dan kemampuan untuk memenuhi standar keamanan yang telah ditetapkan. ${ }^{26}$

Pemenuhan hak ini tentu saja harus melalui prosedur tertentu, baik yang diselesaikan secara damai (non litigation) maupun yang diselesaikan melalui pengadilan (litigation). Hak untuk mendapatkan penyelesaian hukum ini sebenarnya meliputi juga hak untuk mendapatkan ganti kerugian, tetapi kedua hak tersebut tidak berarti identik. Ganti kerugian dapat diperoleh oleh konsumen tidak harus selalu menempuh upaya hukum terlebih dahulu, sebaliknya, setiap upaya hukum pada hakikatnya berisikan tuntutan memperoleh ganti kerugian oleh salah satu pihak. ${ }^{27}$

25 Ahmadi Miru dan Sutarman Yodo, Hukum Perlindungan Konsumen, Op.cit., hlm. 5.

26 Michael H. Whincup, Contractual Law and Practice the English System and Continental Comparisons, Kluwer Law International, The Hague, 1996, hlm. 147.

27 Shidarta, Hukum Perlindungan Konsumen, Grasindo, Jakarta, 2006, hlm. 30. 
Hak merupakan suatu hal yang sangat erat kaitannya dengan kewajiban, oleh karena itu konsumen tidak dapat memperoleh haknya berupa ganti kerugian apabila belum menunaikan kewajibannya. Kewajiban konsumen diatur dalam Pasal 5 UUPK:

a. Membaca atau mengikuti petunjuk informasi dan prosedur pemakaian atau pemanfaatan barang dan/atau jasa demi keamanan dan keselamatan;

b. Beriktikad baik dalam melaksanakan transaksi pembelian barang dan/atau jasa

c. Membayar sesuai dengan nilai tukar yang disepakati;

d. Mengikuti upaya penyelesaian sengketa perlindungan secara patut.

Kewajiban ini menjadi sangat penting untuk melindungi pelaku usaha dari kesalahan yang dilakukan oleh konsumen, dikarenakan konsumen tidak membaca peringatan yang telah disampaikan kepadanya dengan pengaturan kewajiban ini, memberikan konsekuensi pelaku usaha tidak bertanggung jawab, jika konsumen yang bersangkutan menderita kerugian akibat mengabaikan kewajiban tersebut.

Tanggung jawab untuk memberikan ganti rugi akibat suatu produk cacat tidak akan lahir tanpa adanya pelaku usaha yang membuat produk tersebut, pelaku usaha diartikan sebagai setiap orang atau badan hukum usaha, baik yang berbentuk badan hukum maupun bukan badan hukum yang didirikan dan berkedudukan atau melakukan kegiatan dalam wilayah hukum Indonesia, baik sendiri maupun bersama-sama melalui perjanjian menyelenggarakan kegiatan usaha dalam berbagai bidang ekonomi. ${ }^{28}$

Pengertian pelaku usaha dalam Pasal 1 angka 1 UUPK di atas cukup luas karena meliputi grosir, leveransir, pengecer, dan sebagainya pada pengertian pelaku usaha tersebut, tidaklah mencakup eksportir atau pelaku usaha luar negeri

Subjek hukum baik itu orang perseorangan (naturalijk persoon) maupun badan hukum (recht persoon), memiliki hak dan kewajiban yang melekat pada dirinya begitu pula dengan pelaku usaha. Hak yang dimiliki pelaku usaha yang diberikan UUPK diatur dalam Pasal 6 yaitu:

a. Hak untuk menerima pembayaran yang sesuai dengan kesepakatan mengenai kondisi dan nilai tukar barang dan/atau jasa yang diperdagangkan;

b. Hak untuk mendapatkan perlindungan hukum tindakan konsumen yang beriktikad tidak baik;

c. Hak untuk pembelaan diri sepatutnya di dalam penyelesaian hukum sengketa konsumen;

d. Hak untuk rehabilitasi nama baik apabila terbukti secara hukum bahwa kerugian konsumen tidak diakibatkan oleh barang dan atau jasa yang diperdagangkan;

e. Hak-hak yang diatur dalam ketentuan peraturan perundang-undangan lainnya.

28 Pasal 1 angka 3 Undang-Undang Nomor 8 Tahun 1999 tentang Perlindungan Konsumen. 
Hak pelaku usaha untuk menerima pembayaran sesuai kondisi dan nilai barang dan/atau jasa yang diperdagangkan, menunjukkan bahwa pelaku usaha tidak dapat menuntut lebih banyak jika kondisi barang dan/atau jasa yang diberikannya kepada konsumen tidak atau kurang memadai menurut harga yang berlaku umumnya atas barang dan/atau jasa yang sama. ${ }^{29}$

Hak pelaku usaha yang tersebut pada huruf b, c, d, sesungguhnya merupakan hak-hak yang lebih banyak berhubungan dengan pihak aparat pemerintah dan/atau Badan Penyelesaian Sengketa Konsumen/pengadilan dalam tugasnya melakukan penyelesaian sengketa. Melalui hak-hak tersebut diharapkan perlindungan konsumen secara berlebihan hingga mengabaikan kepentingan pelaku usaha dapat dihindari. ${ }^{30}$

Kewajiban yang dibebankan kepada pelaku usaha sebagai sarana perlindungan hukum bagi konsumen yaitu: ${ }^{31}$

a. Beriktikad baik dalam melakukan kegiatan usahanya;

b. Memberikan informasi yang benar, jelas, dan jujur mengenai kondisi dan jaminan barang dan/atau jasa serta memberi penjelasan penggunaan, perbaikan, dan pemeliharaan;

c. Memperlakukan atau melayani konsumen secara benar dan jujur serta tidak diskriminatif; d. Menjamin mutu barang dan/atau jasa yang diproduksi dan/atau diperdagangkan berdasarkan ketentuan standar mutu barang dan/atau jasa yang berlaku;

e. Memberi kesempatan kepada konsumen untuk menguji dan/atau mencoba barang dan/atau jasa tertentu serta memberi jaminan dan/atau garansi atas barang yang dibuat dan/atau diperdagangkan;

f. Memberi konpensasi, ganti rugi, dan/ atau penggantian apabila barang dan/ atau jasa yang diterima atau dimanfaatkan konsumen tidak sesuai dengan perjanjian.

Kewajiban pelaku usaha beriktikad baik dalam melakukan kegiatan usaha merupakan salah satu asas yang dikenal dalam hukum perjanjian. Ketentuan tentang iktikad baik ini diatur dalam Pasal 1338 KUHPerdata, bahwa perjanjian harus dilaksanakan dengan iktikad baik sedangkan Arrest Hoge Raad di Belanda memberikan peranan tertinggi terhadap iktikad baik dalam tahap pra perjanjian, bahkan kesesatan ditempatkan di bawah asas iktikad baik, bukan lagi pada teori kehendak. ${ }^{32}$

Hak atas ganti kerugian ini dimaksudkan untuk memulihkan keadaan yang telah menjadi rusak (tidak seimbang), akibat adanya penggunaan barang atau jasa yang tidak memenuhi harapan konsumen. ${ }^{33}$

Hak ini sangat terkait dengan penggunaan produk yang telah merugikan konsumen baik yang berupa kerugian materi, maupun

29 Ahmadi Miru dan Sutarman Yodo, Hukum Perlindungan Konsumen, Op.cit., hlm. 50.

30 Ibid, hlm. 51.

31 Pasal 7 Undang-Undang Nomor 8 Tahun 1999 tentang Perlindungan Konsumen.

32 Anonymus.

33 Sidharta, Hukum Perlindungan Konsumen Indonesia, Grasindo, Jakarta, 2006, hlm. 54. 
kerugian menyangkut diri (sakit, cacat, C. Ganti Rugi

bahkan kematian) konsumen.

Hak dan kewajiban yang lekat dengan produsen maupun kosumen, merupakan pengejawantahan dari asas manfaat, asas keadilan, keseimbangan, keamanan, keselamatan konsumen, kepastian hukum, yang memberikan dampak akan tanggungjawab kepada kedua pihak tersebut, bahwa suatu tanggungjawab tidak akan lahir apabila salah satu dari kedua hal tersebut tidak ada. Hak tidak akan terpenuhi apabila kewajiban tidak dilaksanakan begitu pula sebaliknya, kewajiban tidak dapat ditunaikan apabila tidak ada hak yang akan diperoleh. ${ }^{34}$

\section{Ganti rugi menurut Nieuwenheuis,} adalah membayar kerugian yang diderita oleh kreditur, ${ }^{35}$ Mariam Darus Badrulzaman ${ }^{36}$ mengartikan ganti rugi sebagai membayar kerugian yang nyata (feitelijknadee) yang dapat diperkirakan pada saat perikatan itu diadakan yang timbul sebagai akibat ingkar janji (wanprestasi).

Undang-undang menentukan bahwa debitur hanya wajib membayar ganti rugi atas kerugian yang memenuhi dua syarat: ${ }^{37}$

1. Kerugian yang dapat digunakan atau sepatutnya diduga pada waktu perikatan dibuat.

34 Pasal 2 Undang-Undang Republik Indonesia No 8 Tahun 1999 Tentang Perlindungan Konsumen lebih jelas menguraikannya sebagai berikut:

a Asas manfaat, yang berarti mengamanatkan bahwa segala upaya dalam penyelenggaraan perlindungan konsumen harus memberikan manfaat sebesar-besarnya bagi kepentingan konsumen dan pelaku usaha secara keseluruhan. Asas ini intinya adanya bahwa perlindungan konsumen tidak dimaksudkna untuk menempatkan pihak yang satu lebih tinggi dari pihak lain, melainkan adanya kesejajaran sesuai dengan apa yang menjadi haknya atau dengan kata lain penyelenggaraan secara proporsional.

b Asas keadilan, asas ini dimaksudkan agar partisipasi seluruh rakyat dapat diwujudkan secara maksimal dan memberikan kesempatan kepada konsumen dan pelaku usaha untuk memperoleh haknya dan melaksanakan kewajibannya secara adil, sehingga dalam penegakan hukum tidak boleh adanya pandang bulu, tetapi harus melaksanakan sesuai dengan ketentuan yang berlaku.

c Asas keseimbangan, asas ini dimaksudkan untuk memberikan keseimbangan antara kepentingan konsumen, pelaku usaha, dan pemerintah dalam arti materiil dan sprituiil. Selain itu asas ini menghendaki agar konsumen, pelaku usaha atau produsen, pemerintah memperoleh manfaat yang seimbang dari pengaturan dan penegakan hukum perlindungan hukum konsumen. Kepentingan antara konsumen, produsen, dan pemerintah diatur dan harus diwujudkan secara seimbang sesuai dengan hak dan kewajibannya masingmasing dalam kehidupan berbangsa dan bernegara. Tidak ada salah satu pihak yang mendapat perlindungan atas kepentingannya yang lebih besar dari pihak lain sebagai komponen bangsa dan negara.

d Asas keamanan dan keselamatan konsumen, dimaksudkan untuk memberikan jaminan atas keamanan dan keselamatan kepada konsumen dalam penggunaan, pemakaian, dan pemanfaatan barang dan/atau jasa yang dikonsumsi atau digunakan. Asas ini menghendaki adanya jaminan hukum bahwa konsumen akan memperoleh manfaat dari produk yang dikonsumsi/dipakainya, dan sebaliknya bahwaa produk itu tidak akan mengancam ketentraman dan keselamatan jiwa dan harta bendanya.

e Asas kepastian hukum, dimaksudkan agar, baik pelaku usaha maupun konsumen menaati hukum dan memperoleh keadilan dalam penyelenggaraan perlindungan konsumen, serta negara menjamin kepastian hukum. Artinya, undang-undang mengharapakan bahwa aturan-aturan tentang hak dan kewajiban yang terkandung di dalam undang-undang perlindungan konsumen harus diwujudkan dalam kehidupan seharihari sehingga masing-masing pihak memperoleh keadilan.

35 R. Subekti, Hukum Perjanjian, Intermasa, Jakarta, 2002, hlm. 60.

36 Mariam Darus Badrulzaman, KUHPerdata Buku III Hukum Perikatan dengan Penjelasannya, Alumni, Bandung, 1996, hlm. 28.

37 R. Setiawan, Pokok-Pokok Hukum Perikatan, Putra Abardin, Bandung, 1999, hlm. 24. 
2. Kerugian yang merupakan akibat langsung dan serta merta daripada ingkar janji.

Pasal 1247 KUHPerdata menyatakan bahwa debitur hanya mengganti kerugian atas kerugian yang dapat diduga pada waktu perikatan dibuat, kecuali jika ada arglist (kesengajaan). Pasal 1247 ini jelas membedakan antara debitur yang jujur dan debitur yang tidak jujur. Pasal tersebut memakai perkataan arglist dan menurut Hoge Raad di Belanda dalam putusannya tanggal 18 Mei 1923 perkataan itu harus diartikan dengan kwade trouw (tidak jujur). ${ }^{38}$

Debitur jujur dalam pandangan Hoge Raad hanya mempunyai kewajiban untuk memberikan ganti rugi berupa kerugian yang sejak semula dapat dikira akan terjadi. sedangkan apabila debitur tidak jujur, ia juga harus mengganti kerugian yang tidak dapat diperkirakan orang akan terjadi. ${ }^{39}$

Kerugian yang harus dibayarkan harus mempunyai hubungan antara ingkar janji (wanprestasi) dengan kerugian. Jika tidak, maka kerugian tidak harus untuk timbulnya suatu akibat tertentu, terdapat sejumlah syaratsyarat yang tidak terbatas yang mendukung terjadinya akibat tersebut. ${ }^{40}$

Pandangan di atas dapat digambarkan sebagai berikut: A ditabrak oleh sebuah mobil sehingga luka-luka. Faktor-faktor yang menjadi sebab bukan hanya karena sopirnya lalai, akan tetapi juga oleh sebab A telah berbicara dengan $\mathrm{B}$ di jalan dan seterusnya. Tentunya hukum tidak dapat menarik setiap syarat-syarat tersebut sebagai sebab terjadinya akibat. Oleh karena itu maka undang-undang berbicara akibat langsung. ${ }^{41}$

Subekti menyatakan bahwa menurut yuriprudensi, terdapat persyaratan dapat diduga, meliputi besarnya kerugian, sehingga kerugian yang melampaui batas-batas yang dapat diduga, tidak boleh diitimpakan kepada debitur untuk membayarnya kecuali jika ia nyata-nyata telah berbuat secara licik, melakukan tipu daya yang dimaksudkan oleh Pasal 1427 tersebut. ${ }^{42}$

Menurut Asser's-Losecaat Vermeer yang dimaksud jika debitur dengan sengaja dan sadar melanggar akan kewajibannya tanpa menghiraukan ada atau tidaknya maksud daripada debitur untuk menimbulkan kerugian. Dapat diduga harus diartikan objektif, yaitu menurut manusia yang normal timbulnya kerugian tersebut dapat diduga yang harus dapat diduga bukan hanya kerugian akan tetapi juga besarnya kerugian pun harus diduga. ${ }^{43}$

UUPK mengatur bahwa ganti rugi dapat dilakukan melalui beberapa mekanisme:

a. Pengembalian uang;

b. Penggantian barang dan atau jasa yang sejenis atau setara nilainya;

38 Riduan Syahrani, Op.cit., hlm. 224.

39 Ibid, hlm. 224.

40 Ibid, hlm. 24.

41 Anonymus

42 R. Subekti, Op.cit., hlm. 24.

43 Ibid, hlm. 25. 
c. Perawatan kesehatan;

d. Pemberian santunan yang sesuai dengan ketentuan peraturan perundang-undangan yang berlaku. ${ }^{44}$

Ganti rugi dalam UUPK, menganut ganti kerugian subjektif, maksudnya adalah bahwa kerugian yang diderita oleh pihak yang dirugikan, diperhitungkan situasi konkretnya dengan keadaan subjektif diri yang bersangkutan. Memecahkan permasalahan ini terdapat dua teori yaitu: ${ }^{45}$

\section{Conditio Sine Qua Non (Van Buri)}

a. Menurut teori ini suatu akibat ditimbulkan oleh berbagai peristiwa yang tidak dapat ditiadakan untuk ada akibat. Berbagai peristiwa tersebut merupakan satu kesatuan yang disebut "sebab"

b. Ajaran conditio sine qua non ini, berpendapat bahwa semua syaratsyarat yang tidak mungkin ditiadakan untuk adanya akibat adalah senilai dan menganggap setiap syarat adalah sebab. Ajaran ini mendapat tentangan dari berbagai pihak dan tidak mungkin diterapkan dalam praktek hukum, selain itu teori ini memperluas tanggung jawab.

2. Adequate Veroorzaking (Von Kries)

Teori ini berpendapat bahwa suatu syarat merupakan sebab, jika menurut sifatnya sanggup menimbulkan akibat. Hoge Raad memberikan perumusan, bahwa suatu perbuatan merupakan sebab jika menurut pengalaman dapat diharapkan/ diduga akan terjadinya akibat yang bersangkutan.

Koster pada tahun 1962 menyarankan untuk menghapus adequate dan menerima toerrekening naar redelijkheid, faktor penting yang disebut oleh Koster dalam sarannya tersebut adalah:

1. Sifat dari kejadian yang menjadi dasar pertanggung gugat, pada faktor ini konsumen dapat menentukan sifat dari tuntutan ganti rugi yang dapat dijadikan dasar untuk memperhitungkan ganti rugi yang akan diperoleh akibat produk cacat.

2. Sifat kerugian, pada faktor ini pelaku usaha harus dapat memperkirakan terhadap kerugian yang diderita konsumen akibat mengonsumsi atau menggunakan produk yang dihasilkan atau diperdagangkan dan dapat dapat dipertanggungjawabkan kepada pelaku usaha.

3. Besar kecilnya kerugian yang akan diperkirakan akan terjadi, pada faktor ini memberikan pemahaman bahwa konsumen dapat meminta ganti rugi terhadap keuntungan yang akan diperoleh, seandainya produk yang dikonsumsi atau digunakan tersebut tidak termasuk ke dalam kategori produk cacat. 
4. Beban seimbang yang dapat dilakukan bagi pihak tergugat dari kewajibannya untuk membayar ganti rugi, serta memperhatikan keadaan keuangan pihak yang dirugikan. ${ }^{46}$

Brunner berusaha untuk menyusun sejumlah ketentuan untuk menjadi pegangan terhadap kejadian-kejadian yang nyata, apakah kerugian dipertanggungkan oleh satu pihak atau tidak. Berdasarkan pendapat pengadilan, dia merumuskan ketentuan-ketentuan sebagai berikut: ${ }^{47}$

1. Apakah menurut pengalaman, dimungkinkan bahwa suatu akibat yang terjadi lebih dapat dibenarkan untuk mempertanggungkan akibat itu kepada pelaku;

2. Apabila akibat tidak begitu jauh dari perbuatan melanggar hukum, lebih dapat dibenarkan untuk mempertanggungkan akibat itu kepada pelaku;

3. Norma-norma lalu lintas dan norma keselamatan yang bertujuan untuk menghindarkan terjadinya kecelakaan, lebih dibenarkan bahwa kerugiankerugian karena kematian dan luka-luka dipertanggungkan kepada pelaku;

4. Kesalahan yang terjadi apabila membawa kerugian itu lebih besar, dapat dipertanggungkan kepada pelaku secara luas.

Hak ganti rugi ini harus dipahami sebagai upaya untuk mengembalikan keadaan konsumen yang dirugikan kepada keadaan seandainya produk tersebut tidak dikonsumsi atau digunakan.

Bentuk ganti rugi yang digunakan lazimnya ialah uang, karena menurut para ahli hukum perdata maupun menurut yuriprudensi, uang merupakan alat yang paling praktis, yang paling sedikit menimbulkan selisih dalam menyelesaikan sengketa. Bentuk lain yang dapat digunakan untuk pembayaran ganti rugi dapat berupa: pemulihan keadaan semula (in natura) dan larangan untuk mengulangi, pengingkaran akan kedua bentuk ganti rugi ini dapat diperkuat dengan uang paksa. ${ }^{48}$

Penentuan besarnya ganti rugi yang harus dibayarkan, pada dasarnya harus berpegang pada asas bahwa ganti rugi yang harus dibayar sedapat mungkin membuat pihak yang rugi dikembalikan pada kedudukan semula. Seandainya tidak terjadi kerugian, atau dengan kata lain ganti kerugian menempatkan sejauh mungkin orang yang dirugikan dalam kedudukan yang seharusnya andaikata perjanjian dilaksanakan secara baik atau tidak terjadi perbuatan melanggar hukum. ${ }^{49}$

Pasal 1246 KUHPerdata, ganti rugi terdiri dari faktor, yaitu:

a. Kerugian yang nyata-nyata diderita;

b. Keuntungan yang seharusnya diperoleh.

Kedua faktor tersebut dicakup dalam

\footnotetext{
46 Anonymus.

47 Ahmadi Miru dan Sutarman Yodo, Hukum Perlindungan Konsumen, Op.cit., hlm. 139.

48 Mariam Darus Badrulzaman, Op.cit., hlm. 30.

49 Ahmadi Miru dan Sutarman Yodo, Op.cit., hlm. 134.
} 
pengertian biaya, kerugian, bunga. Biaya adalah pengeluaran-pengeluaran nyata, misalnya biaya notaris, biaya perjalanan, dan seterusnya. Kerugian adalah berkurangnya kekayaan kreditur sebagai akibat ingkar janji dan bunga adalah keuntungan yang seharusnya diperoleh kreditur jika tidak ingkar janji.

Bunga atau keuntungan yang diharapkan sebagaimana yang tersebut di atas dibagi menjadi 4 (empat) jenis yaitu: ${ }^{50}$

Pertama, bunga konvensional, adalah bunga uang yang dijanjikan pihak di dalam perjanjian (Pasal 1249 KUHPerdata).

Kedua, bunga moratoire adalah membayar sejumlah uang, penggantian biaya rugi dan bunga yang disebabkan karena terlambatnya pelaksanaan perikatan hanya terdiri atas bunga yang ditentukan oleh undang-undang (Pasal 1250 KUHPerdata).

Ketiga, bunga compestaoire adalah bunga uang yang harus dibayar debitur (penjual) untuk mengganti bunga yang dibayar kreditur (pembeli), pada pihak lain karena debitur tidak memenuhi perikatan atau kurang baik melaksanakan perikatan.

Keempat, bunga berganda adalah bunga yang diperhitungkan dari bunga hutang pokok yang tidak dilunasi oleh debitur.

Bunga di atas dibedakan dengan bunga pada sistem perbankan konvensional kecuali bunga berganda yang dikategorikan bunga produktif diartikan sebagai pembiayaan yang berbentuk pinjaman (kredit) dengan bunga yang telah ditetapkan sebelumnya, oleh pihak bank itu sendiri. ${ }^{51}$

Penentuan ganti rugi pun dapat dilakukan dengan memperhitungkan:

Pertama, manfaat yang akan diperoleh dengan menghitung seluruh kerugian yang diderita oleh korban;

Kedua, Pengurangan ganti rugi uang bagi korban, apabila kerugian tersebut disebabkan pula oleh korban;

Ketiga, Hakim dapat mengurangi kewajiban untuk membayar ganti rugi berdasarkan kepada pertimbangan yang logis..$^{52}$

Pasal 19 ayat (2) UUPK memberikan pedoman tentang jumlah, bentuk, atau wujud ganti rugi, yaitu:

1. Pengembalian uang; atau

2. Penggantian barang dan/atau jasa sejenis atau setara nilainya; atau

3. Perawatan kesehatan; dan/atau

4. Pemberian santunan; sesuai dengan peraturan perundangan-undangan.

Penunjukkan Pasal 19 ayat (2) UUPK kepada peraturan perundang-undangan sebagai pedoman, maka dapat dikemukakan ketentuan KUHPerdata. Penentuan tersebut untuk menunjukkan besarnya jumlah ganti

50 Mariam Darus Badrulzaman, Log.cit., hlm. 31-32

51 Yusuf Qardhawi, Bunga Bank Haram, Akbar Media Eka Sarana, Jakarta, 2002, hlm. 147.

52 Arthur S. Hartkamp and Marianne M.M. Tillema, Contract Law in the Netherlands, Kluwer Law International, The Hague, 1995, hlm. 147. 
rugi, KUHPerdata memberikan pedoman, yaitu: $:^{53}$

1. Besarnya ganti kerugian sesuatu dengan fakta tentang ganti kerugian yang benarbenar terjadi dan dialami oleh konsumen;

2. Sebesar kerugian yang dapat diduga sedemikian rupa sehingga keadaan kekayaan dari kreditur harus sama, seandainya debitur memenuhi kewajibannya. Kerugian yang jumlahnya melampaui batas-batas yang dapat diduga tidak boleh ditimpakan kepada debitur.

3. Besarnya kerugian dapat dituntut adalah kerugian, yang merupakan akibat langsung dari peristiwa yang terjadi, yaitu sebagai akibat dari peristiwa perbuatan melawan hukum;

4. Besarnya ganti rugi itu ditentukan sendiri oleh undang-undang, misalnya yang diatur dalam Pasal 1250 KUHPerdata, yang mengatakan, antara lain bahwa dalam tiap-tiap perikatan yang sematamata berhubungan dengan sejumlah uang, penggantian biaya, rugi, dan bunga sekedar disebabkan terlambatnya pelaksanaan, hanya terdiri atas biaya yang ditentukan oleh undang-undang dengan tidak mengurangi peraturan perrundang-undangan khusus. UUPK hanya menentukan batas kerugian berupa sanksi administratif yang ditetapkan oleh Badan Penyelesaian Sengketa Konsumen (BPSK) paling banyak Rp. 200.000.000,00 (dua ratus juta rupiah)
Ganti rugi sebesar isi perjanjian yang dibuat oleh para pihak sebagaimana yang dimungkinkan oleh Pasal 1249 KUHPerdata.

Ganti rugi akibat produk cacat yang mengakibatkan gangguan mental, lukaluka ringan bahkan sampai pada kematian (termasuk di dalamnya biaya pengobatan dan hilangnya keuntungan yang diharapkan) dapat dimintakan, memperluas prinsip ini pihak ketiga dapat mendapatkan ganti rugi pula, dikarenakan telah keluarnya biayabiaya untuk pengurusan korban sebagai contoh: seorang ibu yang rela meninggalkan pekerjaannya demi mengurus anaknya yang terluka atau menyewa seseorang untuk merawat anaknya. ${ }^{54}$

Ganti rugi merupakan bagian dari tanggungjawab pihak yang menyebabkan kerugian baik itu kerugian nyata yang telah terjadi, atau kerugian yang diduga akan timbul di kemudian hari, terhadap pihak yang dirugikan. Tanggung jawab ini lahir karena seandainya tidak terjadi kesalahan yang menyebabkan suatu pihak merugi, tentu tidak akan lahir tanggung jawab untuk mengganti rugi terhadap suatu kerugian.

Ganti rugi pada dewasa ini tidak hanya berada pada ruang lingkup pelaksanaan ganti rugi, melainkan termasuk pula bagaimana bentuk dan besaran ganti rugi. Uang dapat dijadikan sebagai tolak ukur bentuk dan besaran ganti rugi, walapun pada saat tertentu, tidak dapat dijadikan sebagai patokan. 
Contohnya mengganti kerugian akibat kelalaian seorang menyebabkan hilangnya nyawa seseorang dalam peristiwa kecelakaan kendaraan bermotor, terlepas dari hal tersebut uang merupakan alat yang paling rasional dalam ganti rugi dikarenakan sifat praktisnya dalam menyelesaikan suatu persengketaan yang di dalamnya mengandung berbagai kepentingan.

\section{Simpulan}

1. Produsen memiliki tanggung jawab memberikan ganti rugi terhadap kerugian yang dialami atau diderita akibat menggunakan/mengonsumsi produk cacat, dengan memperhatikan kerugian nyata dan yang dapat diduga, dan mempertimbangkan kewajiban konsumen yang menjadi hak produsen telah dilaksanakan.

2. Uang merupakan bentuk ganti rugi yang lazim dan praktis sehingga lebih mudah digunakan untuk membayar suatu kerugian, yang timbul akibat produk cacat sehingga menyebabkan penderitaan bagi konsumen.

\section{DAFTAR PUSTAKA}

\section{Buku}

Abdulkadir Muhammad, 2000, Hukum

Perdata, Citra Aditya Bakti, Bandung. Ahmadi Miru dan Sutarman Yodo, 2005,

Hukum Perlindungan Konsumen, Raja Grafindo Persada, Jakarta. ,2011, Prinsip-Prinsip Perlindungan

Hukum bagi Konsumen di Indo nesia, Rajawali Pers, Jakarta.

\section{A. Z. Nasution, 2001, Hukum Perlindungan}

Konsumen Suatu Pengantar, Diadit

Media, Yogyakarta.

Arthur S. Hartkamp and Marianne M.M. Tillema, 1995, Contract Law in the

Netherlans, Kluwer Law International, the Hague.

Colin Scot and Julian Black, 2000, Craston's

Consumer and the Law (third edition), Butterworths, London.
David Ouhgton and John Lowry, 1997, Text

Book on Consumer Law, Blackstone Press Limited, London, , 1999, Question \& Answers

Law of Torts, Blackstone Press Limited, London.

Mariam Darus Badrulzaman, 1983, KUHPerdata Buku III Hukum Perikatan dengan Penjelasannya, Alumni, Bandung. ，1996, KUHPerdata Buku III Hukum Perikatan dengan Penjelasannya, Alumni, Bandung.

Michael H. Whincup, 1996, Contractual Law and Practice the English System and Continental Comparisons, Kluwer Law International, The Hague. 
R. Setiawan, 1999, Pokok-Pokok Hukum Perikatan, Putra Abardin, Bandung.

R. Subekti, 2002, Hukum Perjanjian, Intermasa, Jakarta.

Riduan Syahrani, 2004, Seluk-Beluk dan Asas-asas Hukum Perdata, Alumni, Bandung.

Shidarta, 2006, Hukum Perlindungan Konsumen, Grasindo, Jakarta.

Widyaningtyas Sistaningrum, 2002, Manajemen Penjualan Produk, Kanisius, Yogyakarta.

Yusuf Qardhawi, 2002, Bunga Bank Haram, Akbar Media Eka Sarana, Jakarta.

\section{Skripsi}

Amaliyah, 2003, Perlindungan Konsumen atas Bahan Tambahan Pangan pada UU No. 8 Tahun 1999 tentang Perlindungan Konsumen jo UU No. 7 Tahun 1996 tentang Pangan, Skripsi Program Sarjana Ilmu Hukum pada Fakultas Hukum Universitas Islam Bandung, tidak dipublikasikan.

\section{Jurnal}

Ridwan Khairandy, 2011, Landasan Filosofis Kekuatan Mengikatnya Kontrak, Jurnal Hukum, Edisi khusus, Oktober 2011, Fakultas Hukum Universitas Islam Indonesia, Yogyakarta.
Sudaryatmo, 2011, Hukum Perlindungan Konsumen dan Implementasinya di Indonesia, Jurnal Hukum Bisnis, Volume 30 No. 1, tahun 2011, Yayasan Pengembangan Hukum Bisnis (YPHB), Jakarta.

\section{Makalah}

Endang Saefullah, 1998, Tanggung Jawab Produsen di Era Perdagangan Bebas (Makalah Seminar Perspektif Hukum Perlindungan Konsumen dalam Era Perdagangan Bebas), Universitas Islam Bandung, Bandung.

\section{Peraturan Perundang-undangan}

Kitab Undang-undang Hukum Perdata.

Undang-undang Republik Indonesia Nomor 8 Tahun 1999 Tentang Perlindungan Konsumen.

\section{Artikel Internet}

Arie Yoenianto, Awas! Obat kuat berbahaya beredar di pasaran http://daerah.sindonews.com/ $\mathrm{read} / 2014 / 03 / 27 / 23 / 848031 /$ awasobat-kuat berbahaya-beredar-di pasaran.

Nurul Arifin, BPOM Surabaya gerebek gudang penyimpanan boraks. http://daerah.sindonews.com/ $\mathrm{read} / 2014 / 03 / 26 / 23 / 848001 /$ bpom-surabaya-gerebek-gudangpenyimpanan-boraks. 